\title{
Quality characteristics and protein digestibility of Protaetia brevitarsis larvae
}

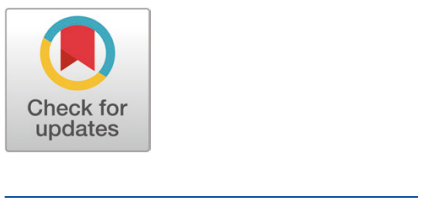

Received: Jul 13, 2020

Revised: Aug 11, 2020

Accepted: Aug 13, 2020

\#These authors contributed equally to this work.

*Corresponding author

Samooel Jung

Division of Animal and Dairy Science

Chungnam National University,

Daejeon 34134, Korea.

Tel: +82-42-821-5774

E-mail: samooel@cnu.ac.kr

Copyright $(2020$ Korean Society of Animal Sciences and Technology.

This is an Open Access article distributed under the terms of the Creative Commons Attribution

Non-Commercial License (http:// creativecommons.org/licenses/by$\mathrm{nc} / 4.0 /$ ) which permits unrestricted non-commercial use, distribution, and reproduction in any medium, provided the original work is properly cited.

ORCID

Seonmin Lee

https://orcid.org/0000-0002-5713-1795

Yun-Sang Choi

https://orcid.org/0000-0001-8060-6237

Kyung Jo

https://orcid.org/0000-0002-3006-5396

Tae-Kyung Kim

https://orcid.org/0000-0002-6349-4314

Hae In Yong

https://orcid.org/0000-0003-0970-4496

Samooel Jung

https://orcid.org/0000-0002-8116-188X

\section{Competing interests}

No potential conflict of interest relevant

to this article was reported.

Funding sources

This research was supported by

\author{
Seonmin Lee ${ }^{1 \#}$, Yun-Sang Choi ${ }^{2 \#}$, Kyung Jo ${ }^{1}$, Tae-Kyung Kim², Hae In Yong ${ }^{2}$ \\ and Samooel Jung ${ }^{1 *}$
}

${ }^{1}$ Division of Animal and Dairy Science, Chungnam National University, Daejeon 34134, Korea

${ }^{2}$ Research Group of Food Processing, Korea Food Research Institute, Wanju 55365, Korea

\begin{abstract}
Herein, the in vitro protein digestibility of lyophilized Protaetia brevitarsis larvae flour with and without defatting using $70 \%$ ethanol was compared with beef loin. Proximate analysis showed that the defatted larvae contained the highest protein content $(p<0.05)$. The viable counts of total aerobic bacteria, Escherichia coli, and coliform bacteria decreased significantly after defatting the larval samples with $70 \%$ ethanol $(p<0.05)$. Measurement of $\alpha$-amino group content and sodium dodecyl sulfate-polyacrylamide gel electrophoresis (SDS-PAGE) revealed higher amounts of low molecular weight proteins in the larvae compared to beef loin $(p<0.05)$. After in vitro digestion, the degree of protein hydrolysis of the digesta was higher for both larvae samples compared to beef loin $(p<0.05)$. No change was observed in the in vitro larval protein digestibility after defatting. These results highlight the excellent protein digestibility of $P$. brevitarsis larvae with high protein content. Defatting insect flour with $70 \%$ ethanol could enhance microbial safety while maintaining excellent protein digestibility.
\end{abstract}

Keywords: Protaetia brevitarsis, Protein digestibility, Edible insect, Beef loin

\section{INTRODUCTION}

In response to the continuous global population growth, the Food and Agriculture Organization (FAO) of the United Nations (UN) has emphasized the need to develop novel and sustainable protein sources $[1,2]$. Edible insects require much smaller breeding areas and release significantly lower carbon emissions than livestock, and their high feed efficiency would meet the protein requirements to ensure human food security [3]. Moreover, edible insects have been evaluated as meat protein substitutes and are rich in fat, minerals, and vitamins, with excellent nutritional and functional properties [4].

The nutritional qualities of dietary proteins are often determined by the total nutrient content as well as digestion and absorption rates in the gastrointestinal tract. The exoskeletons of adult insects consist of chitin-bound sclerotized proteins and glycoproteins [3,5]. The digestive enzyme accessibility and microbial solubility of chitin are low [5]. Marono et al. [6] reported the negative effects of chitin on in vitro protein digestibility in insects and Manditsera et al. [7] observed that protein digestion in adult insects is inhibited due to the high contents of chitin and sclerotized proteins. Thus, the larval stage, with its low chitin and sclerotized protein contents and the absence of the exoskeleton is the main raw material for 
Main Research Program (E0193118-02) of the Korea Food Research Institute (KFRI) funded by the Ministry of Science and ICT (Korea).

\section{Acknowledgements}

Not applicable.

\section{Availability of data and material Upon reasonable request, the datasets of this study can be available from the corresponding author. \\ Authors' contributions Conceptualization: Jung S. \\ Data curation: Lee S. \\ Formal analysis: Jo K, Kim TK, Yong HI. Writing - original draft: Lee S, Choi YS. \\ Writing - review \& editing: Jung S.}

Ethics approval and consent to participate This article does not require IRB/IACUC approval because there are no human and animal participants. protein products [8]. Bosch et al. [4] reported that the protein digestibility of Tenebrio molitor and $\mathrm{Al}$ phitobius diaperinus larvae was approximately $91 \%$. Manditsera et al. [7] reported that insect protein digestibility was approximately $5 \%$ lower than that of whey protein, indicating excellent digestibility.

Although edible insects exhibit excellent nutritional qualities and protein digestibility, consumers are often be bothered by their appearance. Kim et al. [9] surveyed consumer perceptions of entomophagy, showing that approximately $32 \%$ of the respondents indicated they would refuse to eat edible insects in because insects were "disgusting". To overcome this perception, edible insects can be processed by several methods, including grinding and extraction, to mask their appearance when added to food. As insects are generally considered to be rich in fat, protein extraction often involves defatting using organic solvents [10]. Although these processing methods can improve the sensory qualities or functional properties, including flavor, color, and taste of edible insects, protein digestibility can be decreased due to protein denaturation or aggregation during processing [11].

Edible insects that have been temporarily recognized as food ingredients in South Korea include Allomyrina dichotoma and Protaetia brevitarsis larvae. P. brevitarsis larvae are well-known protein sources with excellent physiological qualities and processing abilities [2]. Kim et al. [12] reported the excellent essential amino acid composition and protein quality of $P$. brevitarsis larvae, while Lee et al. [13] reported excellent antioxidant activity. However, to the best of our knowledge, no report has addressed the protein digestibility of P. brevitarsis larvae.

Therefore, the protein digestibility and quality properties of whole and defatted powder of $P$. brevitarsis larvae were investigated in the in vitro protein digestion model and it was compared with a representative animal protein, beef loin.

\section{MATERIALS AND METHODS}

\section{Beef and insect powder}

Beef sirloin (USDA choice grade) frozen at $-20^{\circ} \mathrm{C}$ was purchased from a local market and frozen fasted P. brevitarsis larvae were obtained from Farm bang in Korea and stored at $-70^{\circ} \mathrm{C}$ after freeze-drying. Samples were lyophilized using a freeze-drier (Bondiro, Ilshin, Seoul, Korea) and then pulverized using a model FPM250 grinder (Kenwood, Havant, UK). For defatting P. brevitarsis larvae, $30 \mathrm{~g}$ of ground larvae was added to $600 \mathrm{~mL}$ of $70 \%$ ethanol and homogenized at 13,000 rpm for $1 \mathrm{~min}$ in a model T25 basic apparatus (IKA GmbH \& Co. KG, Staufen im Breisgau, Germany). The homogenate was centrifuged at 6,710×g for $30 \mathrm{~min}$, and the supernatant was removed. After $600 \mathrm{~mL}$ of $70 \%$ ethanol was added to the pellet, the mixture was homogenized and centrifuged again under the same conditions. This process was repeated (total of three times), and the final precipitate was freeze-dried. The freeze-dried beef flour (BF), insect flour (IF), and ethanol-defatted insect flour (IE) were stored at $-20^{\circ} \mathrm{C}$ before analysis.

\section{Proximate composition analysis}

The proximate moisture, crude protein, crude fat, and crude ash compositions of the powder samples were estimated according to AOAC methods [14].

\section{Total aerobic bacteria, Escherichia coli, and coliform bacterial counts}

Total aerobic bacteria, Escherichia coli, and coliform bacterial counts in the powders were determined using previously described methods [15]. Briefly, $3 \mathrm{~g}$ of powder and $27 \mathrm{~mL}$ of sterile saline solution were mixed using a stomacher for $2 \mathrm{~min}$. The mixture was sequentially diluted 10-fold using sterile saline. After incubation in $0.1 \mathrm{~mL}$ of diluent on a solid plate count agar (Difco Laboratories, Detroit, MI, USA) at $37^{\circ} \mathrm{C}$ for $48 \mathrm{~h}$, the total aerobic bacteria were counted. E. coli and coliforms were 
enumerated after dispensing $1 \mathrm{~mL}$ of the diluent in a coliform count plate (3M Health Care, St. Paul, MN, USA) and estimated after incubation at $37^{\circ} \mathrm{C}$ for $24 \mathrm{~h}$. The number of microorganisms is expressed as $\log \mathrm{CFU} / \mathrm{g}$.

\section{In vitro digestion}

The digestive fluid composition was determined using a previously described method [16]. After the protein concentration was adjusted to $48.5 \mathrm{mg} / \mathrm{mL}$ with distilled water, the samples were heated at $80^{\circ} \mathrm{C}$ in a water bath for 30 min to simulate cooking. After cooling, the samples were homogenized at 13,000 rpm for $1 \mathrm{~min}$ (T25 basic). The in vitro digestion of the powder homogenates was performed using a previously described method [17]. After supplementing the homogenate $(4 \mathrm{~mL}$ containing $194 \mathrm{mg}$ protein) with $10 \mathrm{~mL}$ of gastric fluid, the mixture was stirred for $2 \mathrm{~h}$ in a shaking water bath at $37^{\circ} \mathrm{C}$. To simulate small intestinal digestion, $10 \mathrm{~mL}$ of duodenal fluid and $5 \mathrm{~mL}$ of bile solution were added to the chyme and stirred under the same conditions used for the gastric phase. The digesta was immediately frozen at $-70^{\circ} \mathrm{C}$ to terminate the digestion reaction and stored at that temperature until further analysis. The digestion was performed three times (in three batches) on different days for statistical analysis.

\section{Sodium dodecyl sulfate-polyacrylamide gel electrophoresis (SDS-PAGE)}

The powder and digestive fluid samples were homogenized after distilled water was added to achieve a final protein content of $149.4 \mathrm{mg} / \mathrm{mL}$ (T25 basic). The final volume of the homogenate was adjusted to $10 \mathrm{~mL}$ using distilled water. The homogenate and digested samples were mixed in a $2 \times$ sample buffer (125 mM Tris-HCl, 20\% glycerol, 2\% SDS, 2\% mercaptoethanol, and $0.02 \%$ bromophenol blue) at a $1: 1(\mathrm{w} / \mathrm{w})$ ratio, and then heated at $95^{\circ} \mathrm{C}$ in a heating block. For the $12.5 \%$ SDS-PAGE, $10 \mu \mathrm{L}$ of the sample ( $74.7 \mu \mathrm{g}$ protein) and $5 \mu \mathrm{L}$ of pre-stained protein ladder (3454A, TaKaRa Bio, Shiga, Japan) were loaded and run at $20 \mathrm{~mA}$ for $240 \mathrm{~min}$ in running buffer containing 0.1\% SDS, $25 \mathrm{mM}$ Tris, and $192 \mathrm{mM}$ glycine using pagerRun (AE-6531 mPAGE, ATTO, Tokyo, Japan). The protein bands were stained using a mixed solution of Coomassie brilliant blue and 10\% acetic acid and subsequently scanned using a model GS-710 apparatus (Bio-Rad Laboratories, Hercules, CA, USA).

\section{Alpha (a)-amino group content}

To measure the $\alpha$-amino group content of the powder, $10 \mathrm{~mL}$ of $10.4 \%$ trichloroacetic acid was added to $0.4 \mathrm{~g}$ of the powder, followed by homogenization at 13,000 $\mathrm{rpm}$ for $1 \mathrm{~min}$ (T25 basic). The mixture was centrifuged at 2,063×g for $20 \mathrm{~min}$ in a model $1580 \mathrm{R}$ centrifuge (LABOGENE, Lynge, Denmark) and the supernatant was filtered using No. 4 filter paper (Whatman, Maidstone, UK). The hydrolysis rate of the digestion reaction was determined using $1 \mathrm{~g}$ of powder mixed with $6 \mathrm{~mL}$ of $6 \mathrm{~N} \mathrm{HCl}$. Complete digestion was achieved by heating at $100^{\circ} \mathrm{C}$ for $24 \mathrm{~h} \mathrm{[18].}$

The $\alpha$-amino group contents were measured by reacting the samples with o-phthal-dialdehyde (OPA) [19]. The OPA reagent was freshly prepared 20 min before use with a mixture containing $25 \mathrm{~mL}$ of $100 \mathrm{mM}$ sodium tetraborate, $2.5 \mathrm{~mL}$ of $20 \% \mathrm{SDS}, 40 \mathrm{mg} / \mathrm{mL}$ of OPA in methanol, and $100 \mu \mathrm{L}$ of beta-mercaptoethanol. The solution volume was adjusted to $50 \mathrm{~mL}$ with distilled water. For the experiment, $150 \mu \mathrm{L}$ of the sample and $1 \mathrm{~mL}$ of OPA reagent were reacted for $2 \mathrm{~min}$ at room temperature in a model DU ${ }^{\circledR 530}$ spectrophotometer (Beckman Instruments, Brea, CA, USA) to determine the absorbance at $340 \mathrm{~nm}$. Glycine was used to establish a standard curve and the protein content was measured using the Kjeldahl method [14]. The $\alpha$-amino group contents were calculated and reported as $\mu \mathrm{M} \mathrm{NH}_{2} / \mathrm{g}$ protein. The digestive hydrolysis rate (\%) was calculated using the following formula: 
Hydrolysis rate $(\%)=(\alpha$-amino group contents of digesta after in vitro gastrointestinal digestion $/$ $\alpha$-amino group of the digesta after complete hydrolysis $) \times 100$

\section{Statistical analysis}

The examinations were performed in triplicate (three batches) and the data were statistically analyzed using mixed models by a randomized complete block design (each batch corresponding to a block). The least square means and standard error of the least square means are presented, and Tukey's multiple range test was used to distinguish significant differences $(p<0.05)$. SAS version 9.3 software (SAS Institute, Cary, NC, USA) was used to perform the statistical analyses.

\section{RESULTS AND DISCUSSION}

\section{Proximate composition analysis}

Several studies have investigated the nutritional composition of insect species [3,20]. Edible insects are high-quality protein sources rich in fats and minerals [21]. The crude protein content was significantly higher in IF (66.65\%) and IE (69.28\%) than in BF (59.53\%; Table 1, $p<0.05)$, in agreement with previous studies showing the high protein content of $P$. brevitarsis larvae [22,23]. The protein content of the insect samples increased after defatting $(p>0.05)$, as observed previously [12], likely due to the fat removal resulting in an increased crude protein content in IE. The crude ash content of IF was significantly higher than that of $\mathrm{BF}(p<0.05)$, but no significant difference was observed between those of IE and BF ( $p>0.05)$.

The crude fat content was highest in $\mathrm{BF}$, and no significant differences were observed between IE and IF. Previous studies have reported decreased crude fat content after defatting of edible insects with organic solvents, but this was not observed herein. The differences in the crude fat content are likely due to the different larval defatting methods used. Kim et al. [12] and Purschke et al. [24] defatted for $>1 \mathrm{~h}$ after adding hexane to the insect powder. Zhao et al. [25] defatted mealworms by immersion in $99.5 \%$ ethanol overnight. However, $70 \%$ ethanol was used herein as the defatting solvent for a short time, which may be the reason for the lack of a significant decrease in fat content of $P$. brevitarsis larvae during defatting.

\section{Total aerobic bacteria, Escherichia coli, and coliform bacterial counts}

Although the physicochemical and functional properties of edible insect proteins have been evaluated, limited studies have been conducted regarding their microbiological properties [21]. Herein, the counts of total aerobic bacteria, E. coli, and coliform bacteria were determined to monitor changes in the potential microbiological properties before and after defatting with ethanol (Table 2). The total aerobic bacteria of IF was significantly higher than that of BF (8.71 vs. $1.52 \mathrm{Log} \mathrm{CFU} / \mathrm{g}$; $p<0.05)$, while $E$. coli and coliform bacteria were not observed in the $\mathrm{BF}$, but were present in $\operatorname{IF}(0.81$

Table 1. Proximate composition (\%) of the samples

\begin{tabular}{lcccc}
\hline \multicolumn{1}{c}{ Treatment } & Moisture & Crude protein & Crude fat & Crude ash \\
\hline IE & $3.17^{\mathrm{A}}$ & $69.28^{\mathrm{A}}$ & $24.48^{\mathrm{B}}$ & $3.08^{\mathrm{B}}$ \\
$\mathrm{IF}$ & $1.36^{\mathrm{AB}}$ & $66.65^{\mathrm{A}}$ & $26.81^{\mathrm{B}}$ & $5.18^{\mathrm{A}}$ \\
$\mathrm{BF}$ & $0.00^{\mathrm{B}}$ & $59.53^{\mathrm{B}}$ & $37.42^{\mathrm{A}}$ & $3.16^{\mathrm{B}}$ \\
$\mathrm{SEM}^{1)}$ & 0.692 & 2.797 & 1.230 & 0.403 \\
\hline
\end{tabular}

\footnotetext{
${ }^{1)}$ Standard error of the least square mean $(n=9)$.

${ }^{A, B}$ Different capital letters in the same column indicate significant differences between the means $(p<0.05)$.

$\mathrm{IE}$, insect flour defatted with $70 \%$ ethanol; IF, insect flour; BF, beef flour.
} 
Table 2. Total aerobic bacteria, Escherichia coli, and coliform counts (Log CFU/g) of the samples

\begin{tabular}{lccc}
\hline \multicolumn{1}{c}{ Treatment } & Total aerobic bacteria & Escherichia coli & Coliform \\
\hline IE & $5.37^{\mathrm{B}}$ & $\mathrm{ND}^{\mathrm{B}}$ & $\mathrm{ND}^{\mathrm{B}}$ \\
$\mathrm{IF}$ & $8.71^{\mathrm{A}}$ & $0.81^{\mathrm{A}}$ & $5.71^{\mathrm{A}}$ \\
$\mathrm{BF}$ & $1.52^{\mathrm{C}}$ & $\mathrm{ND}^{\mathrm{B}}$ & $\mathrm{ND}^{\mathrm{B}}$ \\
$\mathrm{SEM}^{1)}$ & 0.129 & 0.138 & 0.015 \\
\hline
\end{tabular}

"Standard error of The least square mean $(n=9)$.

${ }^{A-C}$ Different capital letters in the same column indicate significant differences between the means $(p<0.05)$.

IE, insect flour defatted with $70 \%$ ethanol; ND, not detected; IF, insect flour; BF, beef flour.

and $5.71 \mathrm{Log} \mathrm{CFU} / \mathrm{g}$, respectively; $p<0.05)$. Insects are bred in close contact with soil or sawdust in containers contaminating the surface and body of insects with microbes during breeding [21,26]. In addition, contamination of edible insects by spores present in the feed has been reported [21], which may explain the increased the number of total aerobic bacteria, E. coli, and coliform bacteria in the IF samples compared to BF samples.

Total aerobic bacteria in IE was $5.37 \mathrm{Log} \mathrm{CFU} / \mathrm{g}$, significantly lower than that in the IF group $(p<0.05)$, while $E$. coli and coliform bacteria were not detected in IE. Previous studies have also reported the antibacterial effect of the 70\% ethanol defatting procedure. Crippen and Sheffield [27] showed that the outer layer of the mealworm was removed and microorganism number reduced by $60 \%$ when treated with $70 \%$ ethanol. The main mechanisms underlying the antibacterial effects of ethanol involve protein denaturation and aggregation. The hydroxyl group $(-\mathrm{OH})$ in ethanol binds to the proteins of the microorganisms by forming the hydrogen bonds resulting in the damage to their structure and functionality [28]. Thus, the sterilizing effect of ethanol is due to the inhibition of microbial enzymes and protein degradation. Ingram [29] reported that ethanol treatment induced cross-linkage of peptidoglycans and degraded E. coli. Because as fat can be dissolved by ethanol, the waxy layer constituting the larval surface might be solubilized and ethanol penetration increased [27].

Ethanol has been reported to exhibit low toxicity as a fat extraction solvent and applying $70 \%$ ethanol in the extraction process of insect powder is expected to reduce the number of aerobic bacteria [30,31]. However, to use edible insects as food ingredients, standard specifications, or sterilization methods must be systematically established for safety purposes.

\section{a-Amino group content and SDS-PAGE}

Free amino acids and small three to four residue peptides are soluble in $10 \%$ trichloroacetic acid (TCA) [16]. The $\alpha$-amino group content of the 10\% TCA soluble fraction was measured to compare the content of small amino groups in the insect and beef samples (Table 3). The $\alpha$-amino group content of IF was $152.88 \mu \mathrm{M} / \mathrm{g}$, significantly higher than that of $\mathrm{BF}(27.53 \mu \mathrm{M} / \mathrm{g} ; p<0.05)$.

Table 3. The $10 \%$ trichloroacetic acid (TCA) soluble $\alpha$-amino group content $(\mu \mathrm{M} / \mathrm{g})$ of the samples

\begin{tabular}{lc}
\hline \multicolumn{1}{c}{ Treatment } & $\alpha$-amino group content $(\mu \mathrm{M} / \mathbf{g})$ \\
\hline $\mathrm{IE}$ & $34.65^{\mathrm{B}}$ \\
$\mathrm{IF}$ & $152.88^{\mathrm{A}}$ \\
$\mathrm{BF}$ & $27.53^{\mathrm{C}}$ \\
$\mathrm{SEM}^{1)}$ & 1.314 \\
\hline
\end{tabular}

${ }^{1}$ Standard error of the least square mean $(n=9)$.

${ }^{A-C}$ Different capital letters in the same column indicate significant differences between the means $(p<0.05)$.

IE, insect flour defatted with $70 \%$ ethanol; IF, insect flour; BF, beef flour. 
Thus, P. brevitarsis larvae flour contains larger amounts of small peptides and free amino acids compared to BF. Bioactive peptides exhibit antioxidant, antihypertensive, and mineral-binding activities [32] and several studies have confirmed the presence of low molecular weight bioactive peptides in edible insects including P. brevitarsis larvae [32-35]. Previous studies have reported the presence of innate proteases in insect bodies [36,37]. In live insects, innate proteases participate in the defense system, while Bang et al. [36] and Chang et al. [37] reported that serine proteases are present in the larvae and maggot of P. brevitarsis. Autolysis can be caused by the degradation of skin and muscle proteins by endogenous proteases [18]. Moreover, Tonheim et al. [38] reported that autolysis of proteins in the insect can occur even during extraction. Therefore, the high content of the $\alpha$-amino group in IF may be due to autolysis caused by innate proteases.

IE showed decreased $\alpha$-amino group content $(34.65 \mu \mathrm{M} / \mathrm{g}$ ), significantly lower than that of IF ( $p$ $<0.05$ ). The hydroxyl radicals present in $70 \%$ ethanol can bind to insect proteins and induce protein denaturation and aggregation [28]. Liu and Xiong [39] reported decreased $\alpha$-amino group content following the oxidation and denaturation of meat proteins. Ethanol use for fat extraction may reduce the $\alpha$-amino group content via protein polymerization and aggregation.

These trends were also observed by SDS-PAGE (Fig. 1). The BF bands were evenly distributed at all molecular weights and a high intensity band was observed migrating with a molecular mass exceeding $200 \mathrm{kDa}$, likely a myosin heavy chain [39]. However, most insect bands migrated with a molecular mass of $<45 \mathrm{kDa}$. According to Kim et al. [12], bands under $20 \mathrm{kDa}$ in insect samples are likely anti-freeze and hemolymph proteins with molecular weights below approximately 13

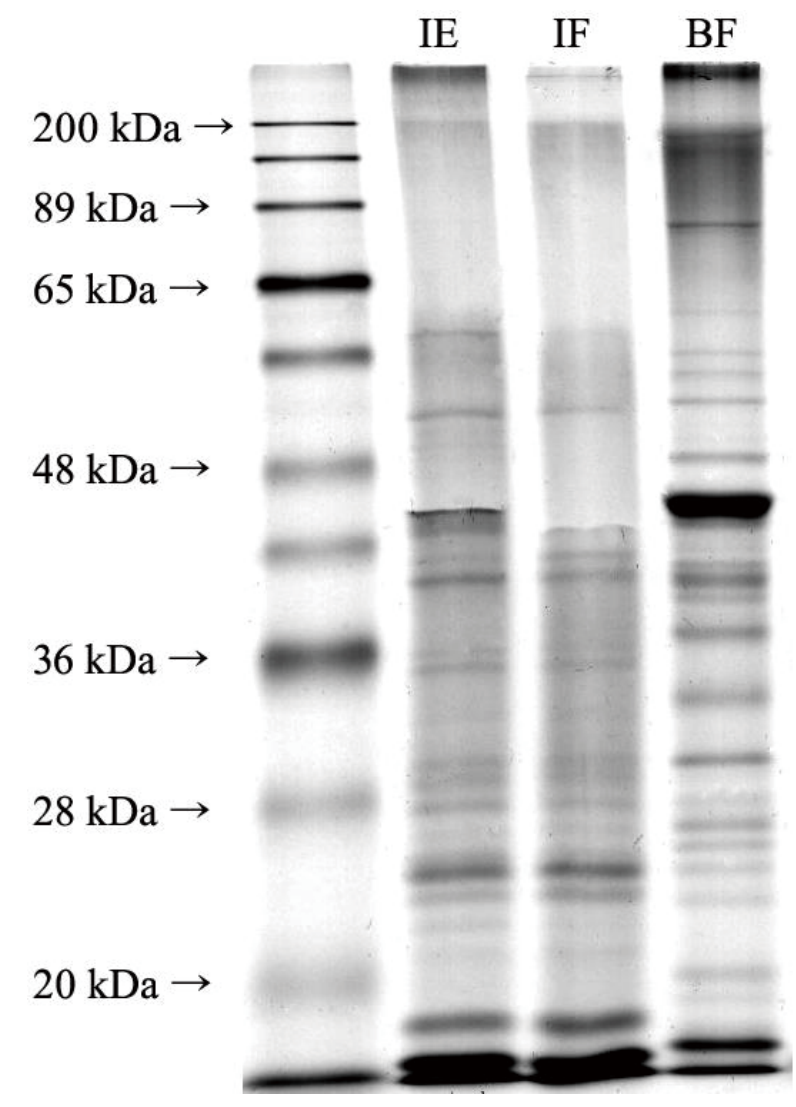

Fig. 1. Sodium dodecyl sulfate-polyacrylamide gel electrophoresis (SDS-PAGE) electrophoretogram of the samples. IE, insect flour defatted with $70 \%$ ethanol; IF, insect flour; BF, beef flour. 
$\mathrm{kDa}$. Herein, it was confirmed that the molecular weight distribution of the proteins present in the $P$. brevitarsis larvae flour and BF differed significantly.

Differences in band distribution and intensity were observed before (IF) and after (IE) defatting. IE displayed bands over $200 \mathrm{kDa}$, while IF did not. In addition, a band near $60 \mathrm{kDa}$ was faintly visible in the IF, while the same band was present at a relatively high intensity in IE. These changes in band intensities and distribution could be due to the denaturation or aggregation of proteins during the ethanol defatting process.

The SDS-PAGE results and $\alpha$-amino group contents of the larvae flour indicated that P. brevitarsis larvae contain more low molecular weight peptides and amino acids compared to BF. Thus, defatting with ethanol likely induces larval protein denaturation.

\section{Protein digestibility and gastrointestinal digesta SDS-PAGE}

Protein digestibility is often used to evaluate protein quality and the digestibility of animal proteins is excellent $[16,40]$. Thus, it is necessary to evaluate insect protein digestibility if they are to replace animal proteins in the human diet. The in vitro protein digestibility of IF was $54.91 \%$, similar to that of BF (50.58\%; Table 4). Kinyuru et al. [11] reported that the in vitro protein digestibility of insects is similar to that of meat and whey proteins. However, Jonas-Levi and Martinez [41] suggested that insect protein digestibility is overestimated by glycoproteins bound to chitin, which cannot be digested in vivo. Because adult insects have sclerotized proteins and chitin in their exoskeleton, concerns have been raised regarding their digestion in the human digestive tract. Therefore, as Finke [8] reported that larvae can be easily digested because of their soft body and low chitin content, larvae were used to as a protein source with the potential to replace meat proteins. The in vitro protein digestibility of P. brevitarsis larvae was considered to be excellent, similar to that of beef. The protein digestion rate can be increased by processing through the structural changes of proteins and inactivation of anti-nutritional factors that bind to proteins, inhibiting digestion [42]. Janssen et al. [43] observed that oxidation-related denaturation and aggregation of proteins during processing decreased protein digestibility by reducing their accessibility towards digestive enzymes. Megido et al. [42] reported that in vitro protein digestibility increased during the boiling and baking of mealworms in an oven. However, Kinyuru et al. [11] reported decreased in vitro protein digestibility during the baking and drying of grasshoppers. These differences likely originate from the various degrees of protein denaturation during processing. Herein, aggregation occurred in the larvae protein after defatting, as indicated by the results of $\alpha$-amino group content and SDS-PAGE. However, the digestibility of the larva after defatting did not significantly differ (Table 4). Chamba et al. [44] confirmed that the surface hydrophobicity of soybean protein extract increased after defatting with hexane. Most proteins have a hydrophobic core consisting of internal non-polar amino acids, while their exterior is composed of polar amino acids [45]. External factors can alter surface hydrophobicity and digestive accessibility of the proteins. As the ordered structures of proteins loosened to form an irregular shape due to physiochemical damage during processing, aliphatic amino acids, includ-

Table 4. Degree of hydrolysis (\%) of the in vitro gastrointestinal digesta

\begin{tabular}{lc}
\hline \multicolumn{1}{c}{ Treatment } & Protein digestibility \\
\hline $\mathrm{IE}$ & 46.58 \\
$\mathrm{IF}$ & 54.91 \\
$\mathrm{BF}$ & 50.58 \\
$\mathrm{SEM}^{1)}$ & 2.518 \\
\hline
\end{tabular}

${ }^{11}$ Standard error of the least square mean $(n=9)$.

$\mathrm{IE}$, insect flour defatted with $70 \%$ ethanol; IF, insect flour; BF, beef flour. 
ing leucine, isoleucine, and valine, are exposed to the surface, and hydrogen bonds are collapsed [46]. Protein aggregation occurred in IE, but some buried hydrophobic groups may have been exposed to the outside during defatting by ethanol. Moreover, pepsin exhibits substrate specificity for aromatic amino acids, including phenylalanine, tyrosine, and tryptophan [47]. If defatting with 70\% ethanol induced an increase in surface hydrophobicity in IE, the digestive accessibility of pepsin to phenylalanine and tryptophan may have increased [48]. Therefore, no significant differences in in vitro protein digestibility were observed between IE and IF, as protein aggregation and unfolding occurred at the same time in the insect proteins.

The SDS-PAGE results for the in vitro gastrointestinal digesta indicated excellent in vitro protein digestibility of $P$. brevitarsis larvae and beef loin (Fig. 2). All bands in the sample (Fig. 1) disappeared after digestion (Fig. 2), where only bands below $36 \mathrm{kDa}$ were recognizable and were present only at extremely low intensities. This indicated that the proteins in the P. brevitarsis larvae and beef loin were cleaved by digestive enzymes during in vitro digestion and could not be observed in the $12.5 \%$ gel. In addition, a 20\% SDS-PAGE was run to examine smaller molecular weight bands, and a few recognizable bands were evident in the gel (data not shown).

The observed proteolysis was lower than that reported previously by Kinyuru et al. [11], with the in vitro protein digestibility of grasshopper of $>80 \%$. Bosch et al. [4] demonstrated that the in vitro digestibility of T. molitor and A. diaperinus exceeded 91\%, but Janssen et al. [43] reported that the in vitro digestibility of T. molitor, A. diaperinus, and Hermetia illucens was 10\%-30\%. Manditsera et al. [7] confirmed that the in vitro digestibility of Eulepida mashona and Henicus whellani was $30.6 \%$ and

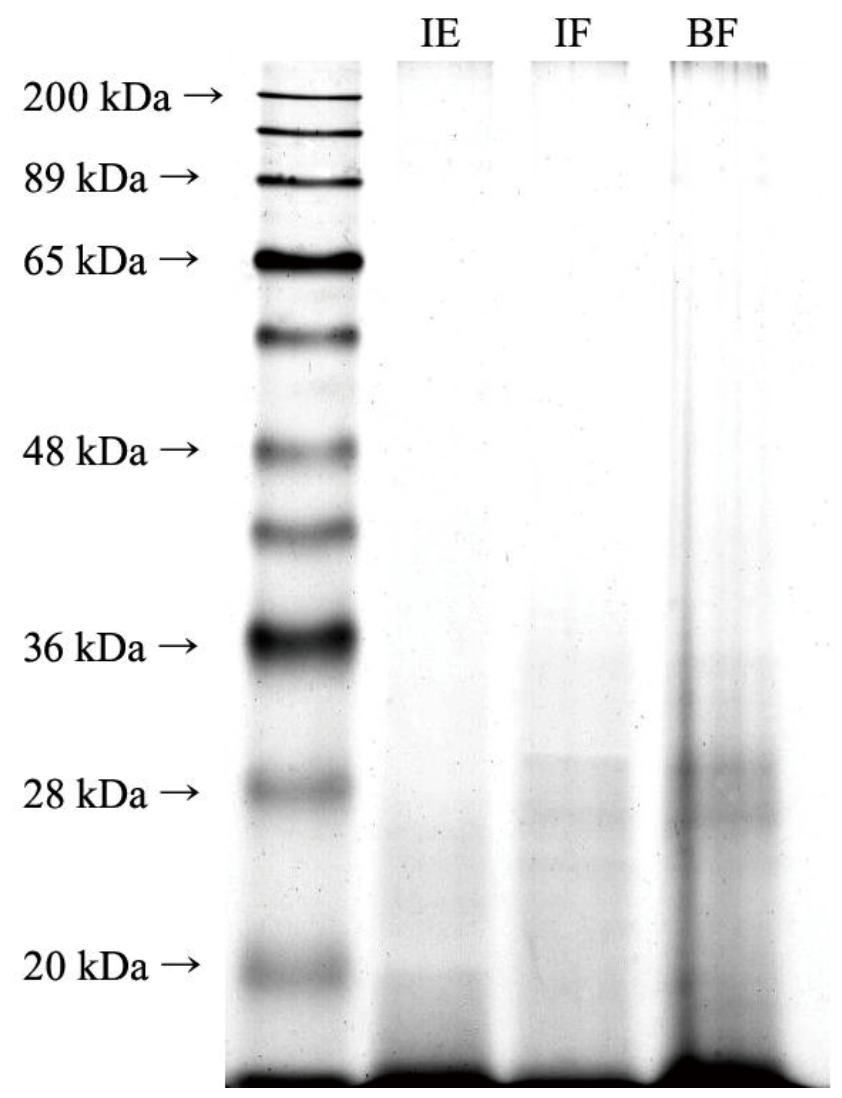

Fig. 2. Sodium dodecyl sulfate-polyacrylamide gel electrophoresis (SDS-PAGE) electrophoretogram of the in vitro gastrointestinal digesta. IE, insect flour defatted with $70 \%$ ethanol; IF, insect flour; $B F$, beef flour. 
$29.7 \%$, respectively. These differences can be attributed to the design of the in vitro digestion model, method of evaluating protein digestibility, types of edible insects examined, and the breeding stage [7]. Therefore, the absolute value of the in vitro protein digestibility obtained herein differed from those previously reported.

In conclusion, the proximate composition of the samples indicated a high crude protein content in P. brevitarsis larvae. Defatting insect samples with $70 \%$ ethanol reduced the total aerobic bacteria, $E$. coli, and coliform counts. Small molecular weight amino acids and peptides were more evident in the insect samples compared to the beef samples. Although defatting IF with $70 \%$ ethanol induced a decrease in the $\alpha$-amino group content in IE, no significant differences in in vitro protein digestibility were observed among the three sample treatments. Therefore, larvae of $P$. brevitarsis exhibited excellent protein digestibility and crude protein content, showing great potential as a substitute for beef protein. Furthermore, defatting the larvae of P. brevitarsis with 70\% ethanol increased microbial safety without impairing the in vitro protein digestibility.

\section{REFERENCES}

1. Verhoeckx KCM, van Broekhoven S, den Hartog-Jager CF, Gaspari M, de Jong GAH, Wichers HJ, et al. House dust mite (Der p 10) and crustacean allergic patients may react to food containing Yellow mealworm proteins. Food Chem Toxicol. 2014;65:364-73. https://doi. org/10.1016/j.fct.2013.12.049

2. Park ES, Choi MK. Recognition, purchase, and consumption of edible insects in Korean adults. J Nutr Health. 2020;53:190-202. https://doi.org/10.4163/jnh.2020.53.2.190

3. Kim TK, Yong HI, Kim YB, Kim HW, Choi YS. Edible insects as a protein source: a review of public perception, processing technology, and research trends. Food Sci Anim Resour. 2019;39:521-40. https://doi.org/10.5851/kosfa.2019.e53

4. Bosch G, Zhang S, Oonincx DG, Hendriks WH. Protein quality of insects as potential ingredients for dog and cat foods.J Nutr Sci. 2014;3:e29. https://doi.org/10.1017/jns.2014.23

5. Bosch G, Vervoort JJM, Hendriks WH. In vitro digestibility and fermentability of selected insects for dog foods. Anim Feed Sci Technol. 2016;221:174-84. https://doi.org/10.1016/j.anifeedsci.2016.08.018

6. Marono S, Piccolo G, Loponte R, Di Meo C, Attia YA, Nizza A, et al. In vitro crude protein digestibility of Tenebrio molitor and Hermetia illucens insect meals and its correlation with chemical composition traits. Ital J Anim Sci. 2015;14:3889. https://doi.org/10.4081/ ijas.2015.3889

7. Manditsera FA, Luning PA, Fogliano V, Lakemond CMM. Effect of domestic cooking methods on protein digestibility and mineral bioaccessibility of wild harvested adult edible insects. Food Res Int. 2019;121:404-11. https://doi.org/10.1016/j.foodres.2019.03.052

8. Finke MD. Estimate of chitin in raw whole insects. Zoo Biol. 2007;26:105-15. https://doi. org/10.1002/zoo.20123

9. Kim JY, Kang WG, Baek IH, Kim YS, Kim HW, Min GG, et al. A survey study on the therapy bugs and edible insects. J Anim Assisted Psychother. 2017;6:59-67. https://doi. org/10.16896/kaaap.2017.6.2.59

10. Choi BD, Wong NA, Auh JH. Defatting and sonication enhances protein extraction from edible insects. Korean J Food Sci Anim Resour. 2017;37:955-61. https://doi.org/10.5851/kosfa.2017.37.6.955

11. Kinyuru JN, Kenji GM, Njoroge SM, Ayieko M. Effect of processing methods on the in vitro protein digestibility and vitamin content of edible winged termite (Macrotermes subhylanus) 
and grasshopper (Ruspolia differens). Food Bioprocess Technol. 2010;3:778-82. https://doi. org/10.1007/s11947-009-0264-1

12. Kim TK, Yong HI, Jeong CH, Han SG, Kim YB, Paik HD, et al. Technical functional properties of water-and salt-soluble proteins extracted from edible insects. Food Sci Anim Resour. 2019;39:643-54. https://doi.org/10.5851/kosfa.2019.e56

13. Lee HS, Ryu HJ, Song HJ, Lee SO. Enzymatic preparation and antioxidant activities of protein hydrolysates from protaetia brevitarsis larvae. J Korean Soc Food Sci Nutr. 2017;46:116470. https://doi.org/10.3746/jkfn.2017.46.10.1164

14. AOAC [Association of Official Analytical Chemists] International. Official methods of analysis of AOAC International. 18th ed. Washington, DC: AOAC International; 2010.

15. Jung S, Kim HJ, Park S, Yong HI, Choe JH, Jeon HJ, et al. The use of atmospheric pressure plasma-treated water as a source of nitrite for emulsion-type sausage. Meat Sci. 2015;108:1327. https://doi.org/10.1016/j.meatsci.2015.06.009

16. Lee S, Jo K, Hur SJ, Choi YS, Kim HJ, Jung S. Low protein digestibility of beef puree in infant in vitro digestion model. Food Sci Anim Resour. 2019;39:1000-7. https://doi.org/10.5851/kosfa.2019.e73

17. Kim HS, Hur SJ. Effect of six different starter cultures on the concentration of residual nitrite in fermented sausages during in vitro human digestion. Food Chem. 2018;239:556-60. https:// doi.org/10.1016/j.foodchem.2017.06.160

18. Yi L, Van Boekel MA, Boeren S, Lakemond CM. Protein identification and in vitro digestion of fractions from Tenebrio molitor. Eur Food Res Technol. 2016;242:1285-97. https://doi. org/10.1007/s00217-015-2632-6

19. Church FC, Swaisgood HE, Porter DH, Catignani GL. Spectrophotometric assay using o-phthaldialdehyde for determination of proteolysis in milk and isolated milk proteins. J Dairy Sci. 1983;66:1219-27.https://doi.org/10.3168/jds.S0022-0302(83)81926-2

20. Kim TK, Yong HI, Chun HH, Lee MA, Kim YB, Choi YS. Changes of amino acid composition and protein technical functionality of edible insects by extracting steps. J Asia-Pac Entomol. 2020;23:298-305. https://doi.org/10.1016/j.aspen.2019.12.017

21. Stoops J, Crauwels S, Waud M, Claes J, Lievens B, Van Campenhout L. Microbial community assessment of mealworm larvae (Tenebrio molitor) and grasshoppers (Locusta migratoria migratorioides) sold for human consumption. Food Microbiol. 2016;53:122-7. https://doi. org/10.1016/j.fm.2015.09.010

22. Chung MY, Hwang JS, Goo TW, Yun EY. Analysis of general composition and harmful material of Protaetia brevitarsis. J Life Sci. 2013;23:664-8. https://doi.org/10.5352/ JLS.2013.23.5.664

23. Kim SK, Weaver CM, Choi MK. Proximate composition and mineral content of five edible insects consumed in Korea. CyTA J Food. 2017;15:143-6. https://doi.org/10.1080/19476337.2 016.1223172

24. Purschke B, Tanzmeister H, Meinlschmidt P, Baumgartner S, Lauter K, Jäger H. Recovery of soluble proteins from migratory locust (Locusta migratoria) and characterisation of their compositional and techno-functional properties. Food Res Int. 2018;106:271-9. https://doi. org/10.1016/j.foodres.2017.12.067

25. Zhao X, Vázquez-Gutiérrez JL, Johansson DP, Landberg R, Langton M. Yellow mealworm protein for food purposes-extraction and functional properties. PLOS ONE. 2016;11:e0147791. https://doi.org/10.1371/journal.pone.0147791

26. Banjo AD, Lawal OA, Adeyemi AI. The microbial fauna associated with the larvae of Oryctes monocerus.J Appl Sci Res. 2006;2:837-43. 
27. Crippen TL, Sheffield C. External surface disinfection of the lesser mealworm (Coleoptera: Tenebrionidae).J Med Entomol. 2006;43:916-23. https://doi.org/10.1093/jmedent/43.5.916

28. Yoo JH. Review of disinfection and sterilization-back to the basics. Infect Chemother. 2018;50:101-9. https://doi.org/10.3947/ic.2018.50.2.101

29. Ingram LO. Mechanism of lysis of Escherichia coli by ethanol and other chaotropic agents. J Bacteriol.1981;146:331-6. https://doi.org/10.1128/jb.146.1.331-336.1981

30. Undeland I, Härröd M, Lingnert H. Comparison between methods using low-toxicity solvents for the extraction of lipids from herring (Clupea harengus). Food Chem. 1998;61:355-65. https://doi.org/10.1016/s0308-8146(97)00053-8

31. Fajardo AR, Cerdán LE, Medina AR, Fernández FGA, Moreno PAG, Grima EM. Lipid extraction from the microalga Phaeodactylum tricornutum. Eur J Lipid Sci Technol. 2007;109:120-6. https://doi.org/10.1002/ejlt.200600216

32. Nongonierma AB, FitzGerald RJ. Unlocking the biological potential of proteins from edible insects through enzymatic hydrolysis: a review. Innovative Food Sci Emerging Technol. 2017;43:239-52. https://doi.org/10.1016/j.ifset.2017.08.014

33. Yoon HS, Lee CS, Lee SY, Choi CS, Lee IH, Yeo SM, et al. Purification and cDNA cloning of inducible antibacterial peptides from Protaetia brevitarsis (Coleoptera). Arch Insect Biochem Physiol. 2003;52:92-103. https://doi.org/10.1002/arch.10072

34. Hwang JS, Kang BR, Kim SR, Yun EY, Park KH, Jeon JP, et al. Molecular characterization of a defensin-like peptide from larvae of a beetle, Protaetia brevitarsis. Int J Ind Entomol. 2008;17:131-5.

35. Dai C, Ma H, Luo L, Yin X. Angiotensin I-converting enzyme (ACE) inhibitory peptide derived from Tenebrio molitor (L.) larva protein hydrolysate. Eur Food Res Technol. 2013;236:681-9. https://doi.org/10.1007/s00217-013-1923-z

36. Bang K, Hwang S, Lee J, Cho S. Identification of immunity-related genes in the larvae of Protaetia brevitarsis seulensis (Coleoptera: Cetoniidae) by a next-generation sequencing-based transcriptome analysis.J Insect Sci. 2015;15:142. https://doi.org/10.1093/jisesa/iev120

37. Chang JH, Jo JY, Kim YJ, Lee SY, Cho HJ, You SN, et al. Biochemical characterization of a protease with fibrinolytic activity from maggots of Protaetia brevitarsis.J Life Sci. 2007;17:60612. https://doi.org/10.5352/jls.2007.17.5.606

38. Tonheim SK, Nordgreen A, Høgøy I, Hamre K, Rønnestad I. In vitro digestibility of water-soluble and water-insoluble protein fractions of some common fish larval feeds and feed ingredients. Aquaculture. 2007;262:426-35. https://doi.org/10.1016/j.aquaculture.2006.10.030

39. Liu G, Xiong YL. Electrophoretic pattern, thermal denaturation, and in vitro digestibility of oxidized myosin.J Agric Food Chem. 2000;48:624-30. https://doi.org/10.1021/jf990520h

40. Lee S, Jo K, Lee HJ, Jo C, Yong HI, Choi YS, et al. Increased protein digestibility of beef with aging in an infant in vitro digestion model. Meat Sci. 2020;169:108210. https://doi. org/10.1016/j.meatsci.2020.108210

41. Jonas-Levi A, Martinez JJI. The high level of protein content reported in insects for food and feed is overestimated. J Food Compos Anal. 2017;62:184-8. https://doi.org/10.1016/j.jfca.2017.06.004

42. Megido RC, Poelaert C, Ernens M, Liotta M, Blecker C, Danthine S, et al. Effect of household cooking techniques on the microbiological load and the nutritional quality of mealworms (Tenebrio molitor L. 1758). Food Res Int. 2018;106:503-8. https://doi.org/10.1016/ j.foodres.2018.01.002

43. Janssen RH, Vincken JP, Arts NJ, Fogliano V, Lakemond CM. Effect of endogenous phenoloxidase on protein solubility and digestibility after processing of Tenebrio molitor, Alphitobius 
diaperinus and Hermetia illucens. Food Res Int. 2019;121:684-90. https://doi.org/10.1016/ j.foodres.2018.12.038

44. Chamba MVM, Hua Y, Katiyo W. Oxidation and structural modification of full-fat and defatted flour based soy protein isolates induced by natural and synthetic extraction chemicals. Food Biophys. 2014;9:193-202. https://doi.org/10.1007/s11483-014-9333-8

45. Zhang M, Zhao D, Zhu S, Nian Y, Xu X, Zhou G, et al. Overheating induced structural changes of type I collagen and impaired the protein digestibility. Food Res Int. 2020;134:109225. https://doi.org/10.1016/j.foodres.2020.109225

46. He J, Zhou G, Bai Y, Wang C, Zhu S, Xu X, et al. The effect of meat processing methods on changes in disulfide bonding and alteration of protein structures: impact on protein digestion products. RSC Adv. 2018;8:17595-605. https://doi.org/10.1039/c8ra02310g

47. Adams GE, Posener ML, Bisby RH, Cundall RB, Key JR. Free radical reactions with proteins and enzymes: the inactivation of pepsin. Int J Radiat Biol Relat Stud Phys Chem Med. 1979;35:497-507. https://doi.org/10.1080/09553007914550611

48. Öncel Ş, Uzun L, Garipcan B, Denizli A. Synthesis of phenylalanine-containing hydrophobic beads for lysozyme adsorption. Ind Eng Chem Res. 2005;44:7049-56. https://doi.org/10.1021/ ie0506318 